12. Official Journal of the European Union L276/33. Directive 2010/63 / EU of the European parliament and of the council of 22 September 2010 on the protection of animals used for scientific purposes. 86/609 / EC.20.10.2010.

13. Horyachkovskiy, A. G. (1998). Clinical biochemistry [Clinical biochemistry]. Odessa: Astroprint, 572.
14. Vyshtakalyuk, A. B. (2008). Protyvoanemycheskaya activity Polymetal International pectin complexes polisaharidov with $\mathrm{Fe}_{2}+, \mathrm{Co}_{2}+, \mathrm{Cu}_{2}+$ at razlychnom sootnoshenyy d-metals [Protivoanemicheskim activity polymetal pectic polysaccharides complexes with $\mathrm{Fe}_{2}+, \mathrm{Co}_{2}+, \mathrm{Cu}_{2}+$ at various ratios of d-metals]. Chemical and Pharmaceutical Journal, 42 (6), 3-6.

Дата находження рукопису 28.03.2015

Чернадчук Сніжана Сергіївна, кандидат біологічних наук, доцент, кафедра біохімії, Одеський національний університет ім. І. І. Мечникова, вул. Дворянська, 2, м. Одеса, Україна, 65000

E-mail: chuk32@yandex.ru

Рустамова Алія Октай Гизи, кафедра біохімії, Одеський національний університет ім. І. І. Мечникова вул. Дворянська, 2, м. Одеса, Україна, 65000

E-mail: elxanpiraliyev@mail.ru

Будняк Олександр Костянтинович. кандидат біологічних наук, доцент, кафедра біохімії, Одеський національний університет ім. І. І. Мечникова, вул. Дворянська, 2, м. Одеса, Україна, 65000

E-mail: budnyak2005@ukr.net

Петров Сергій Анатолійович. доктор біологічних наук, профессор. кафедра біохімії, Одеський національний університет ім. І. І. Мечникова, вул. Дворянська, 2, м. Одеса, Україна, 65000

УДК 582.26/275

DOI: 10.15587/2313-8416.2015.41503

\title{
PATTERNS OF SAND FRACTIONS INFLUENCE ON MICROALGAE OF THE MARINE COAST
}

\section{(C) A. Snigirova, B. Aleksandrov}

To study effect of grain size on microalgae a new method is proposed: sand of different fractions is glued to the surface of microscope slides. Microalgae abundance was higher on fine sand grains $(<0,25 \mathrm{~mm})$. To forecast microalgae abundance the pattern is proposed depending on size of sand grains

Keywords: phytopsammon, benthos, microalgae, abundance, sand grain composition

3 метою вивчення впливу піщаного трунту на мікроводорості пропонується нова методика: на поверхню предметних стекол приклеюються різні фракиії піску. Чисельність мікроводоростей вірогідно збільшується на дрібних піщинках $(<0,25$ мм). Пропонується модель для прогнозування чисельності мікроводоростей псамону в залежності від розміру піщинок

Ключові слова: фітопсамон, бентос, мікроводорості, чисельність, гранулометричний склад піску

\section{Introduction}

One of the important factors characterizing the sandy coast is the sand grain composition. In the northwestern part of the Black Sea there are beaches with coarse, medium and fine sand. However, in lithology four main fractions of sand are distinguished: rough $(2-1 \mathrm{~mm})$, coarse $(1-0,5 \mathrm{~mm})$, medium $(0,5-0,25 \mathrm{~mm})$ and fine sand $(0,25-0,10 \mathrm{~mm})$ [1]. Smaller fractions are divided into silt $(0,10-0,05 \mathrm{~mm})$, dust $(0,05-0,005 \mathrm{~mm})$ and clay $(<0,005 \mathrm{~mm})$.

The size of sand grains affects the size of the interstitial space, self-purification processes in the coast, the content of nutrients, dissolved organic matter, and as a result, the abundance and biomass of hydrobionts of sandy littoral $[2,3]$. The study of the influence of particle size distribution of sand on marine organisms is one of the main aspects for understanding the functioning of coastal ecosystems $[4,5]$.

\section{Literature review}

A well-known approach to the study of soil microorganisms and algae with the help of fouling glasses was proposed by N. Kholodny and modified by his followers [6], who used clean cover glasses, placing them directly in the soil.

This method in hydrobiology was applied by S.N. Duplakov [7] almost simultaneously with the German researcher E. Hentschel [8] who proposed the term "fouling", and was called the method of artificial substrates. The silicate glass slides used were placed directly in water. A number of experimental works, related to the study of the phytofouling processes on the substrate, were carried out using plates made of various materials, but on a smooth surface.

\section{Aim}

The aim of the study is to research the effect of the sand grain size distribution on the development of 
benthic microalgae, using glass plates with different fractions of sand.

The objectives of the study are: to approve the proposed methodology; to find out the pattern of microalgae distribution on sand of various size; to determine whether this pattern will be different for separate groups of algae.

\section{Materials and research methods}

\subsection{Materials}

In order to study the effect of sand grain size on the development of benthic microalgae, we have devel oped a "substrate for studying the effect of particles size distribution of sand on the development of aquatic organisms" [9]. It lies in use of glass plates coated with different factions of sand (Fig. 1).

The surface of the glass plates $\left(10 \mathrm{~cm}^{2}\right.$ area $)$ were covered with a thin layer of silicon and then strewed by sand of various fractions $<0,25 ; 0,25-0,5 ; 0,5-1 ; 1-2$; 2-3 mm. After solidification of the glue the extra sand was removed. As a result we ve got the transparent plates with 2-3 $\mathrm{mm}$ layer of sand bonded with glue. Glass plates coated with silicon but without sand and clean glass plates were used as controls

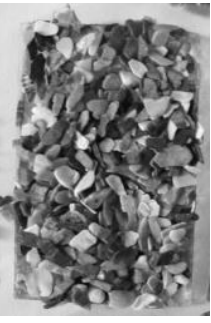

$a$

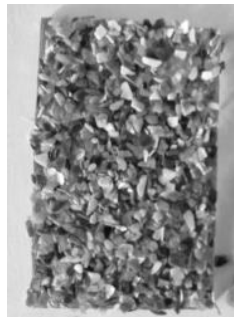

b

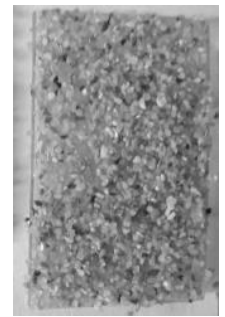

c

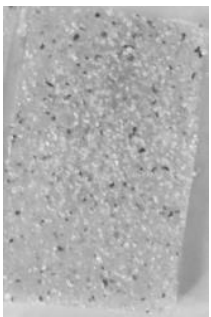

$d$

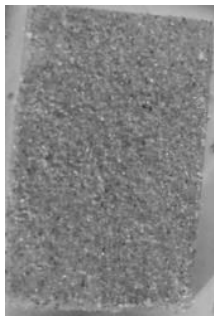

$e$

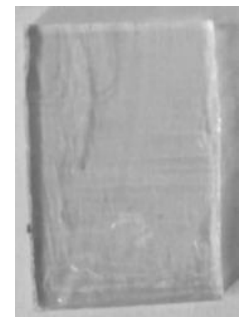

$f$

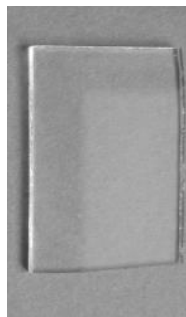

$g$

Fig. 1. Experimental plates with different size of sand grains: $a-2-3 \mathrm{~mm}, b-1-2 \mathrm{~mm}, c-0,5-1 \mathrm{~mm}, d-0,25-0,5 \mathrm{~mm}, e-<0,25, f-$ silicon; $g-$ glass

In total 75 plates with sand and 30 control plates (15 with silicon and 15 glasses) were made. The cell with the plates were filled with marine water and placed on the north side of the laboratory under natural light. The experiment was conducted in August, 2012. The plates were analyzed on the 1st, 3rd, 9th, 15th and 30th days. During the experiment, water temperature ranged from 20,4 to $25,8{ }^{\circ} \mathrm{C}$, salinity $-16,23-22,34 \%$, $\mathrm{pH}-7,58-$ 8,42 . The experiment was tree times replicated.

\section{2. Research methods}

Algological analysis of the data. After the expiry of each phase of the experiment the plate was gently removed from the cell and examined under a microscope for the presence of fouling. For species identification and quantitative analysis of microalgae they were separated from the substrate with rigid brush 3-5 times washing with water and bringing to $15-30 \mathrm{ml}$ volume. The samples were fixed with formaldehyde (4\%). Subsequently, the sample was treated by the standard technique [10]. Nomenclature of diatoms is given in accordance with the system F. Round R. Crawford and D. Mann [11].

For a quantitative study of the microphytobenthos formation packing coefficient of physical surface $\left(\mathrm{S}_{\Sigma} / \mathrm{S}_{0}\right)$ was calculated for each plate [12,13], showing how the surface of the plates with the substrate $\left(\mathrm{S}_{\Sigma}\right)$ differs from smooth surface $\left(\mathrm{S}_{0}\right)$ (Table 1):

\section{$\mathrm{S}_{\Sigma} / \mathrm{S}_{0}=6 / \mathbf{a}$}

where a - sand grains` size, mm (matched mesh size of the sieve).

It should be noted that to prepare the plates we previously used epoxy resin. This material was used to produce permanent preparations in the study of meioben thos and the soil in which it lived [14]. However, the studies have shown toxic effects of epoxy on living microalgae [15], so it was replaced by neutral silicon glue, which is widely used in the manufacture of aquariums.

Statistical analysis of the data. All received data were digitized and put into spreadsheets (Microsoft Excel v. 9.0.).

Table 1

Example of calculating of packing coefficient of physical surface $\left(S_{\Sigma} / S_{0}\right)$ of the plates

\begin{tabular}{|c|c|c|}
\hline $\begin{array}{c}\text { Diameter of sand } \\
\text { particles, mm }\end{array}$ & $\begin{array}{c}\text { Average } \\
\text { diameter, } \mathrm{mm}\end{array}$ & $\mathrm{S}_{\Sigma} / \mathrm{S}_{0}, \mathrm{~mm}^{-1}$ \\
\hline$<0,25(0,25-0,05)$ & 0,15 & 40,00 \\
\hline $0,25-0,5$ & 0,25 & 16,00 \\
\hline $0,5-1$ & 0,75 & 8,00 \\
\hline от 1 до 2 & 1,35 & 4,44 \\
\hline от 2 до 3 & 2,35 & 2,55 \\
\hline 0 (silicon) & 1,00 & 1,00 \\
\hline 0 (glass) & 1,00 & 1,00 \\
\hline
\end{tabular}

\section{Results}

\subsection{Results of the laboratory experiment}

As a result of the study it was established that the diatoms (Bacillariophyta) dominated on the plates within species composition and abundance. There also developed green algae (Chlorophyta) to a lesser extent, Cyanoprokaryota and dinoflagellates (Dinophyta). At almost all plates, Navicula sp., Amphora arcus (Greg.), Attheya decora T. West, Cylindroteca closterium (Ehrenb.) Reimann et J.C. Lewin were represented.

At the initial stages of the experiment microalgae developed rather evenly, reaching the abundance of $1,5-3,3 \cdot 10^{3}$ cells $/ \mathrm{cm}^{2}$ (on the first day) and $2,8-7,5 \cdot 10^{3}$ cells $/ \mathrm{cm}^{2}$ (on the third day) (Table 2 ). 
Table 2

Abundance of microalgae on the experimental plates

\begin{tabular}{|c|c|c|c|c|c|c|c|}
\hline \multirow{2}{*}{$\begin{array}{c}\text { Grains` } \\
\text { size, } \mathrm{mm}\end{array}$} & \multirow{2}{*}{$\mathrm{S}_{\Sigma} / \mathrm{S}_{0}$} & \multicolumn{5}{|c|}{ Average abundance of microalgae, $10^{2}$ cells/ $\mathrm{cm}^{2}$} & \multirow{2}{*}{ Average } \\
\cline { 3 - 6 } & 1 & 1 day & 3 days & 9 days & 15 days & 30 days & \\
\hline 0 (Silicon) & 1 & 25,63 & 54,91 & 260,77 & 463,67 & 226,61 & 206,32 \\
\hline 0 (Glass) & 1 & 23,45 & 39,30 & 44,35 & 208,05 & 450,60 & 153,15 \\
\hline$<0,25$ & 40 & 17,31 & 37,75 & 443,60 & 458,87 & 886,56 & 368,82 \\
\hline $0,25-0,5$ & 24 & 32,78 & 47,41 & 183,84 & 376,27 & 423,85 & 212,83 \\
\hline $0,5-1,0$ & 12 & 25,40 & 100,40 & 228,40 & 427,81 & 507,70 & 257,94 \\
\hline $1,0-2,0$ & 6 & 24,91 & 61,59 & 229,73 & 371,42 & 383,28 & 214,19 \\
\hline $2,0-3,0$ & 3 & 28,41 & 67,69 & 175,20 & 469,12 & 393,16 & 226,72 \\
\hline
\end{tabular}

It is known that the presence of small particles on the substrate helps to increase surface $[13,16]$, thus $1 \mathrm{~cm}^{2}$ of the plate with the smallest size of sand grains $(<0,25 \mathrm{~mm}) 40$ times exceeded the area of the smooth glass.

On the 9th day there was already a significant difference from the control (by 10 times), the largest number was observed on the plates with the sand grain size of $<0,25 \mathrm{~mm}$ and made $443,610^{3} \cdot$ cells $/ \mathrm{cm}^{2}$. At the same period there was an intensive development of diatoms Navicula sp. and A. arcus (Greg.), attached to the surface of the grains, and they subsequently were the most massive representatives.

At further stages of the study the same trend was observed, the number of microalgae gradually increased with the highest abundance on the plates with sand grain size $<0,25 \mathrm{~mm}$ and 0,5 to $1,0 \mathrm{~mm}$. Apparently, these sand fractions are more favorable substrate for the adherent (epipsammic) and movable (epipelic) microalgae, respectively, which is confirmed by literature data [17]. For example, the already mentioned attached diatom $A$. arcus mainly developed on the plates with a smaller particle size, and the motile alga Cylindrotheca closterium bent for larger grains. For typical psammophilous species Attheya decora the increase in the abundance on plates with larger sand grains $(0,5-1$ and 2-3 mm) was observed (Fig. 2).

In the last phases of experiment $(15,30$ days) a positive correlation between microalgae abundance and packing coefficient of physical surface was observed (Fig. 3, Table 3) $(p<0,04)$. This was also characteristic for diatoms, dinoflagellates and cyanobacteria $(\mathrm{p}<0,04)$. Analysis of variance (Table 3 ) for green algae did not give significant results ( $>00,04)$.
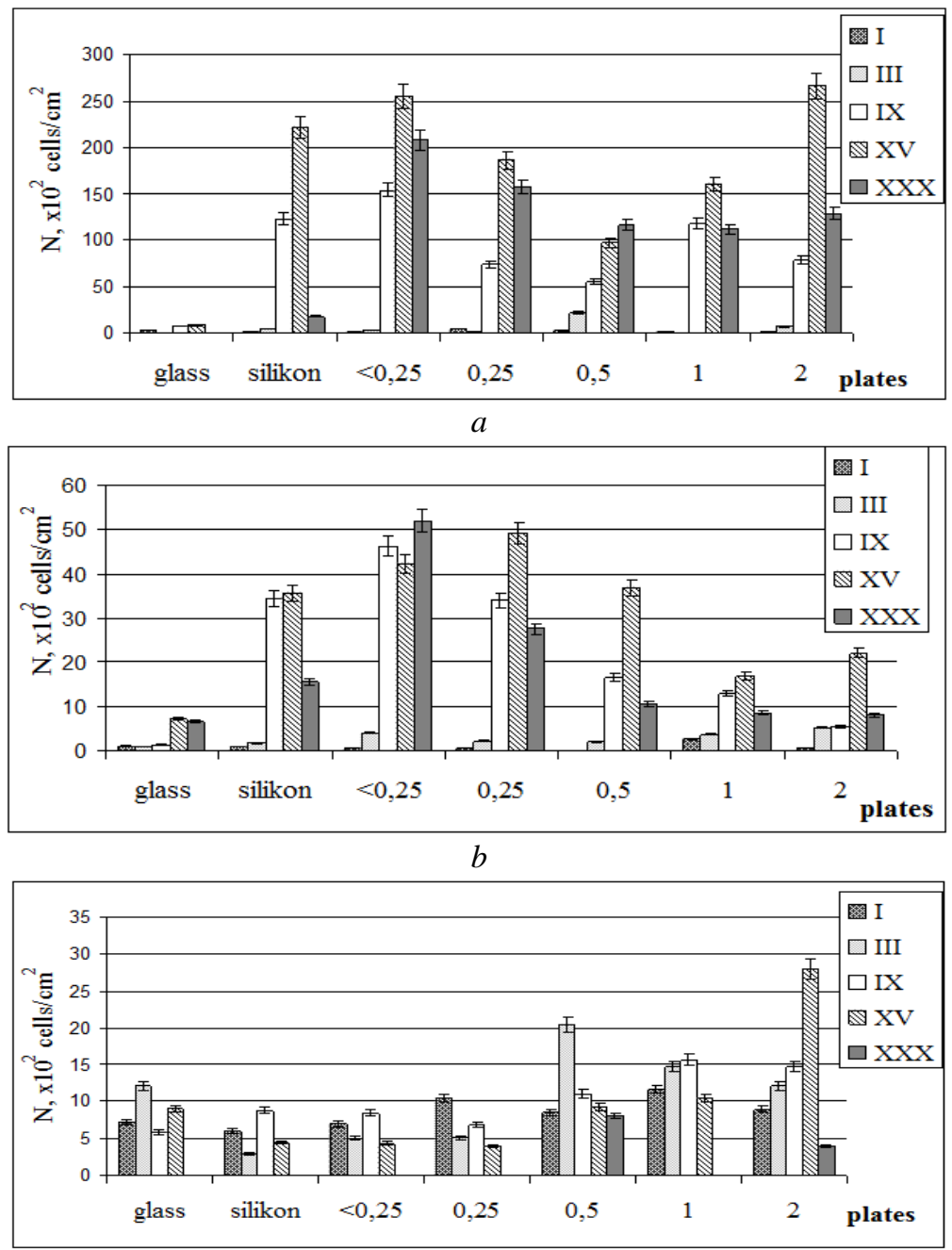

c

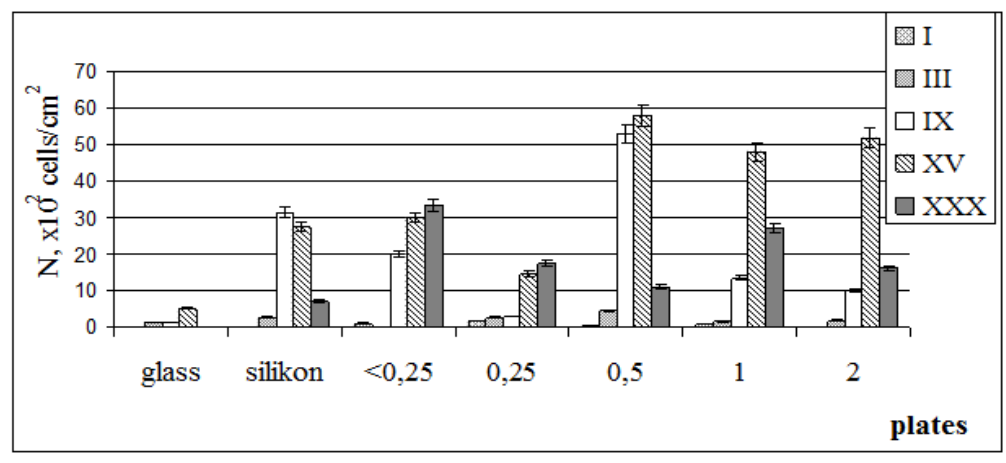

$d$

Fig. 2. Distribution of some species of diatoms (abundance, N) during the experiment: $a$-Navicula sp.; $b$-Amphora arcus; $c$-Attheya decora; $d$-Cylindroteca closterium; I, III, IX, XV, XXX - days 


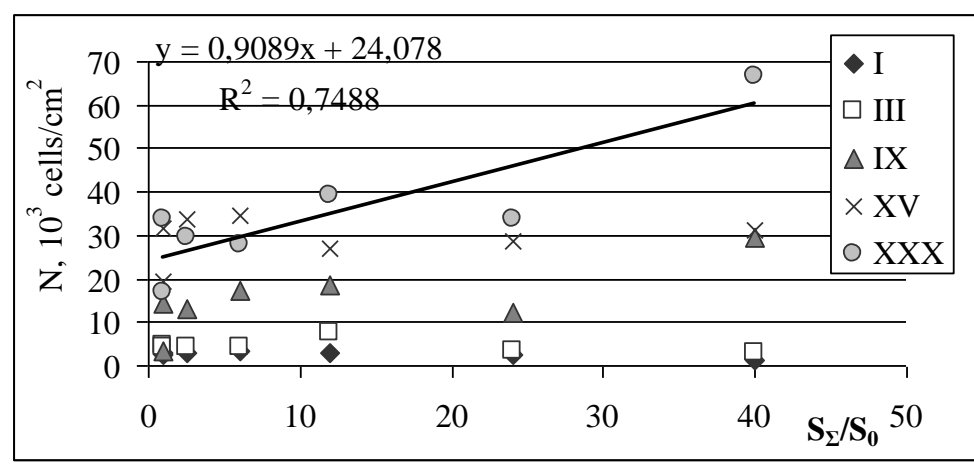

Fig. 3. Dependence of abundance of microalgae on the size of sand grains $\left(\mathrm{S}_{\Sigma} / \mathrm{S}_{0}\right)$ on the base of experimental data (I, III, IX, XV, XXX - days)

Table 3

Results of two ways analysis of variance (ANOVA)

\begin{tabular}{|c|c|c|c|c|c|c|c|c|c|c|}
\hline \multirow{2}{*}{ Variable } & \multicolumn{2}{|l|}{$\mathrm{N}$} & \multicolumn{2}{|l|}{ Bac } & \multicolumn{2}{|c|}{ Din } & \multicolumn{2}{|c|}{ Chlor } & \multicolumn{2}{|c|}{ Cyan } \\
\hline & $\mathrm{P}$ & $\mathrm{F}$ & $\mathrm{P}$ & $\mathrm{F}$ & $\mathrm{P}$ & $\mathrm{F}$ & $\mathrm{P}$ & $\mathrm{F}$ & $\mathrm{P}$ & F \\
\hline $\mathrm{S}_{\Sigma} / \mathrm{S}_{0}$ & $0,01 \times 10^{-15}$ & 2,50 & $0,04 \times 10^{-14}$ & 2,50 & 0,02 & 2,50 & 0,18 & 2,50 & $0,03 \times 10^{-16}$ & 2,50 \\
\hline $\mathrm{t}$, days & $0,02 \times 10^{-1}$ & 2,23 & $0,05 \times 10^{-3}$ & 2,23 & 0,08 & 2,23 & 0,42 & 2,23 & 0,02 & 2,23 \\
\hline
\end{tabular}

Note: $F-$ Fisher's criterion, $P-$ significant level $(<0,04)$.

We shall note that by the end of the experiment cyanobacteria prevailed over diatoms and green algae. Therefore, we can assume that the succession took place on the plates, which consisted of gradual change of different groups of algae. The succession of small species (green algae) took about 30 days, whereas the big cells of diatoms lead their maximum abundance up to the end of the experiment.

\section{2. The patterns of sand grain composition in-} fluence on the microalgae abundance

To verify the results of laboratory experiment the data from field studies were selected. In this set of data 33 samples of phytopsammon were collected on the coast of the Gulf of Odessa in August-October 2006-2008. The samples were collected under the same conditions in the surf zone (0-1 $\mathrm{m}$ from the water's edge) by the described methods [18]. Average temperature of the sea water was $22,9^{\circ} \mathrm{C}$.

For each sample packing coefficient of physical surface $\left(\mathrm{S}_{\Sigma} / \mathrm{S}_{0}\right)$ was calculated on the base of average size of the sand. To calculate the abundance of microalgae formula from fig. 3 was corrected on the base of field data and obtained the following view: $y=2,3 \cdot x+60,2$, where $\mathrm{x}-$ is $\mathrm{S}_{\Sigma} / \mathrm{S}_{0}$. On the basis of the average data the size of microalgae living on the sand grains of a certain size obtained a high correlation with the abundance of psammon microalgae and $S_{\Sigma} / S_{0}(0,8$, Table 4$)$. Thus, on the base of granulometric composition it is possible to forecast up to $80 \%$ the quantitative characteristic of microalgae of the coastal zone.

Different size of sandy fractions unequally affects certain groups of microalgae. Our previous studies [18] show that there were higher abundance of cryptophytae and dinoflagellates on the finer sand. On the base of experimental and field data the patterns for separate phyla of microalgae that are highly represented on the sandy coast are proposed (Table 5). Thus, except the total number of microphytes, there is a certain degree of probabil- ity to predict which groups of algae will predominate on sand with known grain size.

Table 4

The results of forecast for abundance of microalgae

$\left(\mathrm{N}, 10^{3} \cdot\right.$ cells $\left./ \mathrm{cm}^{2}\right)$ depending on the sand grains size $\left(\mathrm{S}_{\Sigma} / \mathrm{S}_{0}\right)$

\begin{tabular}{|c|c|c|}
\hline $\mathrm{S}_{\Sigma} / \mathrm{S}_{0}$ & $\mathrm{~N}_{\text {forecast }}$ & $\mathrm{N}_{\text {real }}$ \\
\hline 5 & 72 & 55 \\
\hline 16 & 96 & 119 \\
\hline 25 & 119 & 130 \\
\hline 40 & 151 & 133 \\
\hline
\end{tabular}

Table 5

Formulas for making the forecasts on the sandy coast with known size of sand grains

\begin{tabular}{|c|c|c|}
\hline Phyllum & Model & $\mathrm{R}^{2}$ \\
\hline Bacillariophyta & $\mathrm{y}=0,0264 \cdot \mathrm{x}^{2}-0,9 \cdot \mathrm{x}+20,2$ & 0,98 \\
\hline Dinophyta & $\mathrm{y}=0,2106 \cdot \mathrm{x}-0,5281$ & 0,95 \\
\hline Cryptophyta & $\mathrm{y}=-0,0243 \cdot \mathrm{x}^{2}-1,541 \cdot \mathrm{x}-6,5$ & 0,96 \\
\hline $\begin{array}{c}\text { Cyanoprokaryo- } \\
\text { ta }\end{array}$ & $\mathrm{y}=0,25 \cdot \mathrm{x}+3,35$ & 0,82 \\
\hline
\end{tabular}

Note: $x$-packing coefficient of physical surface, $R^{2}$-approximation coefficient

\section{Discussion of the results}

The study of the influence of sand particle size distribution on aquatic organisms causes a lot of controversy, and there are still a lot of unanswered questions. A number of studies failed to confirm the importance of sand size fractions on the distribution of organisms [19]. It was demonstrated on the basis of many studies that certain species prefer certain substrate $[20,21]$, whereas others being cosmopolitan do not depend on it.

At the same time, a lot of evidence was found to support the existence of certain adaptations of organisms living in the sand [22], and preferences for certain types of sand [23]. This is mainly due to the animal component 
of sandy coasts [24]. It has been suggested that such sandy substrate parameters as the average grains size, porosity and degree of sorting soil determine the distribution of organisms on the coast $[16,17]$. For the community of benthic diatoms not just the size of sand grains is very important, but their microtopography (surface microrelief of grains) [25].

The proposed approach in the study of microalgae using the plates with fixed sand particles can be used widely in hydrobiological studies for different purposes: such as studying distribution of aquatic organism of different size of sand, studying the character of their successions, etc. General chronology of phytopsammon community successions indicates the duration of experimental studies: 3-15 days - for short-term and 15-30 days for long-term observation.

On the other hand, the results of present study led to reveal the pattern of sand grain composition influence on the microalgae. Combining the empiric and field data, we showed the possibility to forecast the processes in the coastal zone of the sea. Nowadays in the conditions of high interest to study of the contact zones [26, 22] it's great importance to understand the mechanisms of psammocontour functioning. The necessity to establish general laws of development of communities of sandy coasts provides a basis for predicting the formation of microphytobenthos in different regions of the World Ocean, and also allows you to identify particular biocenotic changes at sands with different granulometry, based on common approaches. The process of the energetic metabolism, nutrition, growth and production, through which the biotic cycle of substances is carried out, forms the material basis of the relationship of aquatic organisms. Each of these processes is accompanied with the definite quantity of substances and energy, and the elaboration of the scientific bases for modeling of ecosystems of any level is tightly connected with the quantitative count of role of communities and populations [27].

Therefore, the proposed patterns of influence of sediment character on microalgae could be a good base for development of the concept of sandy beaches functioning.

\section{Conclusions}

1 The proposed approach of study of aquatic organisms using plates with different fractions of sand on silicon can be used in hydrobiological studies.

2. The fine sand fraction increases the surface of the substrate and provides the growth of microalgae abundance.

3 . Thus, on the base of granulometric composition it is possible to forecast up to $80 \%$ the quantitative characteristic of microalgae of the coastal zone using the following pattern: $y=2,3 \cdot x+60,2$.

4 . With a certain degree of probability it is possible to predict which groups of algae (Bacillariophyta, Dinophyta, Cryptophyta, Cyanoprokaryota) will predominate on sand of definite grain size.

\section{References}

1. Rukhin, L. B. Granulometricheskiy metod izucheniya peskov [Text] / L. B. Rukhin. - Lviv: Izd-vo Leningradskogo gosudarstvennogo un-ta, 1947. - $213 \mathrm{p}$.
2. Jonge, V. N. The occurrence of Epipsammic diatom populations: a result of interaction between physical sorting of sediment and sertain properties of diatom species [Text] / V. N. Jonge // Estuarine, coastal and shelf science. - 1985. - Vol. 21, Issue 5. - P. 607-622. doi: 10.1016/0272-7714(85)90061-7

3. Wotton, R. S. Water purification using sand [Text] / R. S. Wotton // Hydrobiologia. - 2002. - Vol. 469. - P. 193-201.

4. Saburova, M. A. Makromasshtabnoye raspredeleniye interstitsial'nogo mikrofitobentosa $\mathrm{v}$ estuarii reki Chernoy (Kandalakshskiy zaliv, Beloye more) [Text] / M. A. Saburova, I. G. Polikarpov, I. V. Burkovskiy et. al. // Ekologiya morya. 2001. - Vol. 58. - P. 7-12.

5. Jewson, D. H. Co-existence of and survival of diatoms on sand grains [Text] / D. H. Jewson, S. F. Lowry, R. Bowen // European Journal of Phycology. - 2006. - Vol. 41, Issue 2. - P. 131-146. doi: 10.1080/09670260600652903

6. Rybalkina, A. V. Izucheniye mikroflory pochvy metodom obrastaniya stekol po N.G. Kholodnomu: rukovodstvo $\mathrm{k}$ prakticheskomu zanyatiyu po mikrobiologii [Text] / A. V. Rybalkina, Ye. V. Kononenko; V. V. Aniknev, K. A. Lukomskaya (Eds.). - M.: Prosveshcheniye, 1977. - P. 76-77.

7. Rukovodstvo po metodam gidrobiologicheskogo analiza poverkhnostnykh vod i donnykh otlozheniy [Text] / V. A. Abakumova (Ed.). - Lviv: Gidrometeoizdat, 1983. - 240 p.

8. Hentschel, E. Die Untersuchungen von Strömen [Text] / E. Hentschel // Abderhalden: Hand. Deutsch. Biol. Arbeitsmeth. - 1925. - Vol. IX, Issue 2. - P. 87-100.

9. Snigirova, A. A. Novyy podkhod v issledovanii mikrovodorosley peschanoy supralitorali [Text] / A. A. Snigirova, B. G. Aleksandrov // Al'gologiya. - 2014. - Vol. 24, Issue 3. - P. 435-439.

10. Arsan, O. M. Metodi gídroyekologíchniy doslídzhen' poverkhnevikh vod [Text] / O. M. Arsan, O. A. Davidov, T. M. D'yachenko et. al.; V. D. Romanenko (Ed.). - NAN Ukraïni. Ín-t gídrobíologîi. - K: LOGOS, 2006. - 408 p.

11. Round, F. E. The Diatoms. Biology and morphology of the genera [Text] / F. E. Round, R. M. Crawford, D. G. Mann. - Cambridge Univ. Press, 1990. - 747 p.

12. Khaylov, K. M. Svyaz' biologicheskikh parametrov fitoobrastaniya s fizicheskimi parametrami eksperimental'nykh «rifovykh» konstruktsiy v yevtrofiruyemoy morskoy akvatorii [Text] / K. M. Khaylov, A. V. Prazukin, M. A. Rabinovich et al. // Vodnyye resursy. - 1994. - Vol. 21, Issue 2. - P. 166-175.

13. Shimek, R. L. Sand Bed Secrets. The Common-Sense Way to Biological Filtration [Text] / R. L. Shimek. - Marc Weiss Companies, Inc. Ft. Lauderdale, Florida, 2001. - 36 p.

14. Rieger, R. M. Resin embedments of quantitative meiofauna samples for ecological and structural studies - Description and application [Text] / R. M. Rieger, E. Ruppert // Marine Biology. - 1978. - Vol. 46, Issue 3. - P. 223-235. doi: 10.1007/bf00390684

15. Snigireva, A. A. Vliyaniye granulometricheskogo sostava grunta na formirovaniye mikrofitobentosa [Text] / A. A. Snigireva, B. G. Aleksandrov // Materialy tret'yey Mezhdunarodnoy nauchnoy konferentsii "Sovremennyye problemy gidrobiologii. Perspektivy. Puti i metody resheniy". Kherson, 2012. - P. 121-124.

16. McLachlan, A. The Ecology of Sandy Shores [Text] / A. McLachlan, A. C. Brown. - Elsevier Inc., 2006. $373 \mathrm{p}$.

17. Saburova, M. A. Makromasshtabnoye raspredeleniye interstitsial'nogo mikrofitobentosa $\mathrm{v}$ estuarii reki Chernoy (Kandalakshskiy zaliv, Beloye more) [Text] / M. A. Saburova, I. G. Polikarpov, I. V. Burkovskiy et. al. // Ekologiya morya. 2001. - Vol. 58. - P. 7-12.

18. Snigirova, A. Benthic microalgae under the influence of beach nourishment in the Gulf of Odessa (the Black 
Sea) [Text] // A. Snigirova // Botanica Lithuanica. - 2013. Vol. 19, Issue 2. - P. 120-128. doi: 10.2478/botlit-2013-0015

19. Ravenel, W.S. The effect of sediment characteristics on the distribution of two subtidal harpacticoid copepod species [Text] / W. S. Ravenel, D. Thistle // Journal of Experimental Marine Biology and Ecology. - 1981. - Vol. 50, Issue 2-3. - P. 287-301. doi: 10.1016/0022-0981(81)90055-1

20. Hennig, H. F.-K. O. Relationships between meiofaunal population densities and physico-chemical properties of unpolluted sandy beaches [Text] / H .F.-K. O. Hennig, A. H. Fricke, P. J. Greenwood et al. // Environmental Monitoring and Assessment. - 1982. - Vol. 1, Issue 4. - P. 337-334. doi: $10.1007 / b f 00403834$

21. Azovsky, A. I. Spatio-temporal variability of microand meiobenthic communities in a White Sea intertidal sandflat [Text] / A. I. Azovsky, E. S. Chertoprood, M. A. Saburova, I. G. Polikarpov // Estuarine, Coastal and Shelf Science. 2004. - Vol. 60, Issue 4. - P. 663-671. doi: 10.1016/ j.ecss.2004.03.005

22. Zaitsev, Yu. A key role of sandy beaches in the marine environment [Text] / Yu. Zaitsev // J. Black Sea/Mediterranean Environment. - 2012. - Vol. 18, Issue 2. P. 114-127.

23. Fenchel, T. Particle size-selection of two deposit feeders: the amphipod Corophium volutator and the prosobranch Hydrobia ulnae [Text] / T. Fenchel, L. H. Kofoed, A. Lappalainen // Marine Biology. - 1975. - Vol. 30, Issue 2. P. 119-128. doi: 10.1007/bf00391586

24. Swedmark, B. The interstitial fauna of marine sand [Text] / B. Swedmark // Biological Reviews. - 1964. - Vol. 39, Issue 1. - P. 1-42. doi: 10.1111/j.1469-185x.1964.tb00948.x

25 . Townsend, S. A. The role of substrate type on benthic diatom assemblages in the Daly and Roper Rivers of the Australian wet/dry tropics [Text] / S. A. Townsend, P. A. Gell // Hydrobiologia. - 2005. - Vol. 548, Issue 1. - P. 101-115. doi: 10.1007/s10750-005-0828-7

26. Zaytsev, Yu. P. Soobshchestvo mikroorganizmov porovykh vod peschanykh plyazhey Chernogo morya [Text] / Yu. P. Zaytsev // Fakty i gipotezy. Míkrobíologíya ta bíotekhnologíya. - 2008. - Vol. 2, Issue 3. - P. 8-20.

27. Aleksandrov, B. G. Gidrobiologicheskiye osnovy upravleniya sostoyaniyem pribrezhnykh ekosistem Chernogo morya [Text] / B. G. Aleksandrov. - Kiyev: Naukova dumka, 2008. -344 p.

\section{References}

1. Rukhin, L. B. (1947). Granulometricheskiy metod izucheniya peskov. Lviv: Izd-vo Leningradskogo gosudarstvennogo un-ta, 213.

2. Jonge, V. N. (1985). The occurrence of Epipsammic diatom populations: a result of interaction between physical sorting of sediment and sertain properties of diatom species. Estuarine, coastal and shelf science, 21 (5), 607-622. doi: 10.1016/0272-7714(85)90061-7

3. Wotton, R. S. (2002). Water purification using sand. Hydrobiologia, 469, 193-201.

4. Saburova, M. A., Polikarpov, I. G., Burkovskiy, I. V. et al. (2001) Makromasshtabnoye raspredeleniye interstitsial' nogo mikrofitobentosa $\mathrm{v}$ estuarii reki Chernoy (Kandalakshskiy zaliv, Beloye more). Ekologiya morya, 58, 7-12.

5. Jewson, D. H., Lowry, S. F., Bowen, R. (2006). Coexistence of and survival of diatoms on sand grains. European Journal of Phycology, 41 (2), 131-146. doi: 10.1080/09670260600652903

6. Rybalkina, A. V., Kononenko, Ye. V.; Aniknev, V. V., Lukomskaya, K. A. (Eds.) (1977). Izucheniye mikroflory pochvy metodom obrastaniya stekol po N.G. Kholodnomu: rukovodstvo k prakticheskomu zanyatiyu po mikrobiologii. Moscow: Prosveshcheniye, 76-77.

7. Abakumova, V. A. (Ed.) (1983). Rukovodstvo po metodam gidrobiologicheskogo analiza poverkhnostnykh vod $\mathrm{i}$ donnykh otlozheniy. Lviv, Gidrometeoizdat, 240.

8. Hentschel, E. (1925). Die Untersuchungen von Strömen. Abderhalden: Hand. Deutsch. Biol. Arbeitsmeth, IX (2), $87-100$.

9. Snigirova, A. A., Aleksandrov, B. G. (2014). Novyy podkhod $\mathrm{v}$ issledovanii mikrovodorosley peschanoy supralitorali. Al'gologiya, 24 (3), 435-439.

10. Arsan, O. M., Davidov, O. A., D'yachenko, T. M. et al.; Romanenka, V. D. (Ed.) (2006) Metodi gídroyekologíchniy doslídzhen' poverkhnevikh vod. NAN Ukraïni, Ín-t gídrobíologii. Kiev: LOGOS, 408.

11. Round, F. E., Crawford, R. M., Mann, D. G. (1990). The Diatoms. Biology and morphology of the genera. Cambridge Univ. Press, 747.

12. Khaylov, K. M., Prazukin, A. V., Rabinovich, M. A. et al. (1994). Svyaz' biologicheskikh parametrov fitoobrastaniya s fizicheskimi parametrami eksperimental'nykh «rifovykh» konstruktsiy $\mathrm{v}$ yevtrofiruyemoy morskoy akvatorii Vodnyye resursy, 21 (2), 166-175.

13. Shimek, R. L. (2001). Sand Bed Secrets. The Common-Sense Way to Biological Filtration. Marc Weiss Companies, Inc. Ft. Lauderdale, Florida, 36.

14. Rieger, R. M., Ruppert, E. (1978). Resin embedments of quantitative meiofauna samples for ecological and structural studies - Description and application. Marine Biology, 46 (3), 223-235. doi: 10.1007/bf00390684

15. Snigireva, A. A., Aleksandrov, B. G. (2012). Vliyaniye granulometricheskogo sostava grunta na formirovaniye mikrofitobentosa Materialy tret'yey Mezhdunarodnoy nauchnoy konferentsii "Sovremennyye problemy gidrobiologii. Perspektivy. Puti i metody resheniy". Kherson, 121-124.

16. McLachlan, A., Brown, A. C. (2006). The Ecology of Sandy Shores, Elsevier Inc., 373.

17. Saburova, M. A., Polikarpov, I. G., Burkovskiy, I. V. et al. (2001). Makromasshtabnoye raspredeleniye interstitsial' nogo mikrofitobentosa $v$ estuarii reki Chernoy (Kandalakshskiy zaliv, Beloye more), Ekologiya morya, 58, 7-12.

18. Snigirova, A. (2013). Benthic microalgae under the influence of beach nourishment in the Gulf of Odessa (the Black Sea). Botanica Lithuanica, 19 (2), 120-128. doi: 10.2478/botlit-2013-0015

19. Ravenel, W. S., Thistle D. (1981). The effect of sediment characteristics on the distribution of two subtidal harpacticoid copepod species. Journal of Experimental Marine Biology and Ecology, 50 (2-3), 287-301. doi: 10.1016/00220981(81)90055-1

20. Hennig, H. F.-K. O., Fricke, A. H., Greenwood, P. J. et al. (1982). Relationships between meiofaunal population densities and physico-chemical properties of unpolluted sandy beaches. Environmental Monitoring and Assessment, 1, 337334. doi: $10.1007 / \mathrm{bf} 00403834$

21. Azovsky, A. I., Chertoprood, E. S., Saburova, M. A., Polikarpov, I. G. (2004). Spatio-temporal variability of microand meiobenthic communities in a White Sea intertidal sandflat. Estuarine, Coastal and Shelf Science, 60 (4), 663-671. doi: 10.1016/j.ecss.2004.03.005

22. Zaitsev, Yu. (2012). A key role of sandy beaches in the marine environment. J. Black Sea/Mediterranean Environment, 18 (2), 114-127.

23. Fenchel, T., Kofoed, L. H., Lappalainen, A. (1975) Particle size-selection of two deposit feeders: the amphipod Corophium volutator and the prosobranch Hydrobia ulnae. Marine Biology, 30 (2), 119-128. doi: 10.1007/bf00391586 
24. Swedmark, B. (1964) The interstitial fauna of marine sand. Biological Reviews, 39 (1), 1-42. doi: 10.1111/ j.1469-185x.1964.tb00948.x

25. Townsend, S. A., Gell, P. A. (2005). The role of substrate type on benthic diatom assemblages in the Daly and Roper Rivers of the Australian wet/dry tropics. Hydrobiologia, 548 (1), 101-115. doi: 10.1007/s10750-005-0828-7
26. Zaytsev, Yu. P. (2008). Soobshchestvo mikroorganizmov porovykh vod peschanykh plyazhey Chernogo morya. Fakty i gipotezy. Míkrobíologíya ta bíotekhnologíya, $2(3), 8-20$.

27. Aleksandrov, B. G. (2008). Gidrobiologicheskiye osnovy upravleniya sostoyaniyem pribrezhnykh ekosistem Chernogo morya. Kiyev: Naukova dumka, 344.

Дата надходження рукопису 20.03.2015

Anastasiya Snigirova, Senior lecturer, Department of Hydrobiology and general ecology, Odessa National Mechnikov University, st. Dvoryanskaya, 2, Odessa, Ukraine, 65000

E-mail: snigireva.a@gmail.com

Borys Aleksandrov, Corresponding member of National Academy of Science of Ukraine, Doctor of Biological Sciences, professor, director, Institute of Marine Biology, Pushkin str., 37, Odessa, Ukraine, 65011

E-mail: borys.aleksandrov@gmail.com 